\title{
Occult Lung Small Cell Carcinoma
}

National Cancer Institute

\section{Source}

National Cancer Institute. Occult Lung Small Cell Carcinoma. NCI Thesaurus. Code C6683.

A small cell lung carcinoma detectable by sputum cytology only. The primary tumor is

undetectable radiographically or during bronchoscopy; therefore, it can not be assessed. 